Rádio e mídias sociais: mediações e interações radiofônicas em plataformas digitais de comunicação.

KISCHINHEVSKY, Marcelo.

Rio de Janeiro: Mauad X, 2016. 152p.

\title{
0 rádio mudou. É expandido. Transbordou para 0 celular e para as redes sociais
}

Izani Pibernat Mustafa ${ }^{1}$

Resumo: A resenha destaca os novos conceitos sobre o rádio contemporâneo apresentados no livro Rádio e mídias sociais: mediações e interações radiofônicas em plataformas digitais de comunicação, de Marcelo Kischinhevsky (Ueri). A obra contém uma pesquisa abrangente sobre as principais mudanças provocadas pela chegada da internet e o surgimento das diferentes e diversas plataformas digitais que possibilitam a convergência digital e a ampliação da divulgação do áudio. O rádio está vivendo uma nova revolução. Está mais abrangente. Pode ser ouvido pelo dial ou pela internet, ao vivo (streaming) ou sob demanda (podcasting) em vários suportes: celular, computadores, notebooks e TV por assinatura. Estamos na era do rádio expandido. Podemos ouvi-lo praticamente em qualquer lugar e a qualquer hora.

Palavras-chave: rádio expandido; mídias sociais; convergência digital; internet

Abstract: Radio and Social Medias: mediations and radiophonic interactions on digital communication platforms by the Marcelo Kischinhevsky (Ueri). The book contains a wide survey on the main changes brought by the arrival of the internet and the emergence of different and diverse digital platforms enabling

1 Universidade do Estado do Rio de Janeiro. Rio de Janeiro, RJ, Brasil. E-mail: izani.mustafa@ gmail.com 
digital convergence and the expansion of audio dissemination. The radio is experiencing a new revolution. It is more widespread. It can be heard by dial or by the internet, live streaming or on-demand (podcasting) on various supports: cell phones, computers, notebooks and pay-TV. We are in the era of expanded radio. We can hear it almost anywhere and anytime.

Keywords: expanded radio; social media; digital convergence; internet 
O rádio, desde seu surgimento, no século XX, passou por diversas transformações. Mudou, teve de se reinventar. Agora, no século XXI, por causa da revolução provocada pela internet e das novas tecnologias, ganhou espaços públicos inimagináveis. Além das ondas hertzianas, é ouvido pela internet, ao vivo (streaming) ou sob demanda (podcasting). Esse é o rádio expandido, conceituado pelo professor doutor e pesquisador da Sociedade Brasileira de Estudos Interdisciplinares da Comunicação (Intercom) Marcelo Kischinhevsky no livro Rádio e mídias sociais: mediações e interações radiofônicas em plataformas digitais de comunicação.

O rádio contemporâneo transbordou para as mídias sociais, para o celular, para a TV por assinatura e portais de música. Estamos na era da convergência digital, que possibilita ouvir uma emissora em diferentes plataformas: celular, smartphones, computadores, tablets e tocadores multimídia. O celular de hoje é o radinho de pilha de ontem.

A obra, dividida em seis capítulos, detalha como o meio de comunicação mais popular, abrangente e tradicional está se recriando. No primeiro capítulo, "O rádio expandido", o autor destaca a expansão da convergência midiática, em função da qual o "rádio foi forçado a se reinventar mais uma vez e, surpreendentemente, mostrou maior capacidade de reação do que outros meios de comunicação" (KISCHINHEVSKY, 2016, p. 13). O rádio, que sempre foi o patinho feio e exerceu papel de coadjuvante entre os veículos de comunicação, renasceu porque se misturou à rede mundial de computadores e ao celular; se reencontrou porque seu alcance vai muito além das ondas hertzianas. Com um celular, é possível sintonizar uma emissora e, atualmente, cada brasileiro tem um aparelho.

No Capítulo 2, "Em busca do radiofônico - perspectivas teóricas", o pesquisador faz uma revisão bibliográfica que perpassa os estudos culturais e a economia política da comunicação para definir o que é rádio. Um meio que transmite sons? Um meio de comunicação que transmite informação sonora? As emissões sonoras que vão além das ondas eletromagnéticas? Sim, é tudo isso. Mas o rádio que, por suas características, 
transmite som, mais do que nunca, tem de informar e prestar um serviço público ao ouvinte e ocupar todas as formas de transmissão, inclusive nas redes sociais como Facebook, Twitter e Instagram.

No Capítulo 3, "Convergência midiática e reconfiguração da indústria da radiodifusão sonora”, Kischinhevsky utiliza referências teóricas da economia política da comunicação para situar a nova fase do rádio. Para ele, a convergência digital é uma "fase de multiplicidade da oferta. Os movimentos são aparentemente contraditórios, mas fazem parte de um claro processo de reordenação empresarial e de transição rumo a suportes digitais" (KISCHINHEVSKY, 2016, p. 43).

O proprietário, coordenador ou apresentador de um programa precisa estar atento aos ouvintes dispersos num ambiente digital, com informações instantâneas e conectados também pelo WhatsApp. Quem está no comando de uma emissora precisa estar conectado às redes sociais e acompanhar as audiências por todos os meios - pelo dial e na internet-, interagindo com o público pelos novos canais de diálogos.

No Capítulo 4, "Para além das ondas hertzianas", o jornalista define as características do rádio expandido, aquele que transbordou e pode ser ouvido em diferentes plataformas. Com a expansão da internet, multiplicaram-se rapidamente as emissoras on-line. Nesse novo tempo, o conteúdo em áudio pode ser gravado e compartilhado com mais rapidez. Os empresários e comunicadores atentos às novas tecnologias podem oferecer diariamente podcastings por meio de sites e redes sociais para serem ouvidos sob demanda, na hora desejada e no meio mais acessível: celular, notebook, computador, televisão etc.

Independente do tipo de transmissão, o que está em jogo nesse novo espaço público - para troca de mensagens, compartilhamento de arquivos, etiquetagem e colaboração na produção de conteúdos e circulação de notícias - é quem tem competência para atrair a atenção dos internautas. Um exemplo, no Brasil, é o portal colaborativo Radiotube (www. radiotube.org.br), um espaço que veicula programas e reportagens radiofônicas e que conta com uma rede de 635 emissoras e quase três mil usuários cadastrados. 
No Capítulo 5, "O rádio também quer ser 2.0 - como as mídias sociais vêm remediando interações comunicacionais", o autor relembra que o "deslumbramento com as novas tecnologias de informação e comunicação encontra paralelos importantes em outros períodos da história humana" (KISCHINHEVSKY, 2016, p. 95). Isto quer dizer que a evolução do rádio sempre acompanhou as necessidades surgidas conforme a sociedade se transformava nas áreas social, cultural, econômica ou política.

Nesse redemoinho de mudanças tecnológicas, convergência digital e transmídia, as interações entre comunicadores, ouvintes, emissoras e dispositivos técnicos de reprodução sonora estão cada vez mais complexas. Mas todas essas transformações, observa o pesquisador, "remontam à própria origem da radiofonia” (KISCHINHEVSKY, 2016, p. 104). Hoje, a convergência está abrindo um leque de ofertas de centenas de conteúdos radiofônicos e a participação do ouvinte está cada vez mais intensa.

Esse é o novo rádio apresentado no livro: o rádio expandido, que se organizou, se estruturou e se reinventou por causa da internet e das possíveis interações auxiliadas por diferentes dispositivos como o celular, aplicativos como o WhatsApp e redes sociais. O rádio nunca morreu. Sempre soube se adaptar às transformações impostas pelos avanços tecnológicos.

O momento é para repensar a produção do conteúdo, já que os ouvintes agora querem interagir - opinando, sugerindo, criticando ou elogiando. Além disso, a interação com os ouvintes tornou-se estratégica para as emissoras que produzem conteúdos jornalísticos, principalmente porque a "participação do público, mencionado ou não na programação em ondas hertzianas, estabelece um novo nível de diálogo, mesmo que em bases desiguais" (KISCHINHEVSKY, 2016, p. 107). Para o autor, o radiojornalismo ganhou dois importantes valores: a interação e a participação.

No último capítulo do livro, "A utopia do dial infinito", o professor enumera alguns resultados da pesquisa de 2014 da Edison Research e 
da Triton Digital que mapeia a audiência do rádio on-line nos Estados Unidos e pondera sobre a distribuição de conteúdos radiofônicos via internet. Segundo ele, o ambiente midiático está em constante reconfiguração e o dial não tem fim. Basta um clique para mudar de estação on-line. Basta um clique numa outra página para que aquelas vozes, aquelas narrativas fiquem para trás. Sejam desligadas, desconectadas.

A obra é, sem dúvida, fundamental para pesquisadores, professores, estudantes e comunicadores. Em tempos de convergência digital, precisamos conhecer o rádio expandido que transbordou para o celular, para a TV por assinatura e para as mídias sociais conectadas e reaprender a produzir conteúdo adequado para os novos ouvintes.

\section{Sobre a autora}

Doutora em Comunicação Social (PUC-RS), mestre em História pela Universidade do Estado de Santa Catarina (Udesc) e graduada em Comunicação Social pela Universidade Federal de Santa Maria (UFSM).

Data de submissão: 29/06/2017

Data de aceite: 23/11/2017 